\title{
Promosi Kesehatan Reproduksi Terhadap Pengetahuan Remaja
}

\author{
Joyce Angela Maria Supit ${ }^{1}$, Freike N Lumy ${ }^{1}$, Els Ivi Kulas ${ }^{1}$ \\ ${ }^{1}$ Mifwifery Department Manado Health Polytechnic/ joyceangelamaria@ gmail.com \\ Email : joycesupit7@gmail.com ; freike.lumy@yahoo.com \\ Naskah Diterima : 02 Januari 2019 Disetujui : Mei $2019 \quad$ Publikasi : Juni 2019
}

\begin{abstract}
ABSTRAK
Latar belakang: Tingkat pengetahuan kesehatan reproduksi merupakan salah satu faktor yang dapat memengaruhi perilaku seksual remaja pranikah. Fenomena akhir-akhir ini menunjukkan bahwa perilaku seksual pranikah remaja diberbagai provinsi semakin meningkat dikarenakan kurangnya pengetahuan remaja tentang kesehatan reproduksi. Permasalahan remaja tersebut memberi dampak sepertikehamilan, pernikahan usia muda, dan tingkat aborsi yang tinggi sehingga dampaknya buruk terhadap kesehatan reproduksi remaja.

Tujuan: Untuk mengetahui pengaruh promosi kesehatan reproduksi terhadap pengetahuan Remaja di SMP Negeri 4 Kecamatan Tomohon Barat Kota Tomohon.

Metode: Penelitian ini adalah rancangan quasi-eksperimental one group pre and posttest design yang dilakukan terhadap 59 sampel, dengan pengumpulan data menggunakan kuesioner yang dibagikan kepada responden sebelum dan sesudah diberikan promosi kesehatan reproduksi. Analisis data menggunakan Wilcoxon Signed Rank Test.

Hasil: Penelitian ini menunjukkan tingkat pengetahuan sebelum diberikan promosi kesehatan paling besar pada kategori kurang sebesar 59,3\% dan setelah diberikan promosi kesehatan tingkat pengetahuan responden paling besar pada kategori baik sebesar 78\%. Hasil analisis menunjukkan nilai $\mathrm{p}=0,01(\mathrm{p}<0,05)$.

Kesimpulan: Ada pengaruh pemberian promosi kesehatan reproduksi kepada remaja. Disarankan program pemberian promosi kesehatan reproduksi dapat dilakukan dengan berkelanjutan baik oleh pihak sekolah maupun pemerintah yang berwenang pada bidang kesehatan sehingga remaja yang rentan terhadap masalah-masalah kesehatan reproduksi dapat berkurang.
\end{abstract}

Kata kunci: Promosi Kesehatan; Kesehatan Reproduksi; Remaja; Pengetahuan

\section{PENDAHULUAN}

\section{World Health Organitation (WHO)} mengkategorikan remaja pada rentang usia 10-19 tahun. Didunia diperkirakan kelompok remaja berjumlah 1,2 milyar atau $18 \%$ dari jumlah penduduk diseluruh dunia, Tingkat pengetahuan kesehatan reproduksi merupakan salah satu faktor yang dapat memengaruhi perilaku seksual remaja pranikah. Fenomena akhir-akhir ini menunjukkan bahwa perilaku seksual pranikah remaja di berbagai provinsi semakin meningkat dikarenakan kurangnya pengetahuan remaja tentang kesehatan reproduksi. Permasalahan remaja tersebut memberi dampak seperti kehamilan, pernikahan usia muda, dan tingkat aborsi yang tinggi sehingga dampaknya buruk terhadap kesehatan reproduksi remaja.

Berdasarkan hasil Survei Demografi Kesehatan Indonesia (SDKI) tahun 2012 bagian Kesehatan Reproduksi Remaja (KRR) dimana sebanyak 11.678 responden 
perempuan $(60.2 \%)$ dan 7.721 responden laki-laki $(39,8 \%)$ mendapatkan informasi tentang kesehatan reproduksi dari teman. Hal ini sama seperti hasil penelitian yang dilakukan Maryatun pada tahun 2013 di SMA Muhammadiyah pada remaja usia 14-17 tahun dengan jumlah responden sebanyak 50 orang, mendapatkan bahwa remaja mendapatkan informasi seksualitas dari teman sebaya sebanyak 36 orang (72\%), 13 orang (26\%) dari orangtua dan 1 orang (2\%) dari guru bimbingan disekolah. (2)

Faktor-faktor yang berhubungan dengan pengetahuan seks bebas pada remaja antara lain adalah hubungan orang tua dengan remaja, pergaulan teman sebaya, dan media informasi. Hubungan orang tua yang harmonis akan menumbuhkan kehidupan emosional yang optimal terhadap perkembangan kepribadian anak remaja. Teman sebaya sangat berpengaruh terhadap kehidupan pada masa-masa remaja karena fenomena yang terjadi dimasyarakat saat ini adalah dimana remaja lebih sering menghabiskan waktu dengan teman sebaya mereka. Pada masa remaja komunikasi dan kepercayaan terhadap orang tua berkurang dan beralih kepada teman sebaya untuk memenuhi kebutuhan dan kedekatan. Remaja yang memiliki hubungan dekat dan berinteraksi dengan pemuda yang lebih tua akan terdorong untuk terlibat dalam kenakalan termasuk juga melakukan hubungan seksual secara dini. Teman sebaya berpengaruh negatif terhadap perilaku seksualitas remaja yang menjadikan panutan atau meniru gaya perilakunya. Remaja yang melakukan hubungan seksual sebelum menikah banyak diantaranya berasal dari keluarga yang bercerai atau pernah bercerai, keluarga dengan banyak konflik dan perpecahan.

Dampak dari seks bebas adalah kehamilan yang tidak diinginkan (unwanted pregnancy), tertular Penyakit Menular Seksual (PMS) termasuk HIV (Human Immunonodeficiency Virus) yang berujung terjadinya penyakit AIDS (Accuired Immuno Deficiency Syndrom). (4)

Berdasarkan latar belakang tersebut, maka tujuan penelitian ini adalah untuk mengetahui pengaruh Promosi Kesehatan Reproduksi terhadap pengetahuan Remaja di SMP Negeri 4 Kecamatan Tomohon Barat Kota Tomohon.

\section{METODE}

Penelitian ini merupakn penelitian analisis kuantitatif dengan pendekatan quasi experimental menggunakan rancangan one group pretest post test untuk mengetahui Promosi Kesehatan 
Reproduksi terhadap Pengetahuan Remaja. Penelitian ini dilakukan sejak bulan Juni 2018 dengan pengumpulan data sekunder di SMP Negeri 4 dan pemberian Promosi kesehatan sekaligus penilaian pretest dan posttest dilaksanakan pada tanggal $22 \mathrm{Juli}$ 2018. Variabel yang diteliti adalah pengetahuan remaja (variabel terikat) kesehatan reproduksi (variabel bebas).

Populasi penelitian ini adalah siswa kelas VII sebanyak 82 siswa dan siswa kelas VIII sebanyak 64 siswa di SMP Negeri 4 Kecamatan Tomohon Barat Kota tomohon, dengan sampel sebanyak 59 siswa yang diambil dengan metode Purposive Sampling. Instrume penelitian yang digunakan pada penelitian ini adalah kuesioner untuk menilai pengetahuan remaja tentang kesehatan reproduksi dan slide yang digunakan untuk memberikan promosi kesehatan dengan metode ceramah. Analisis univariat dilakukan untuk menentukan sebaran data dan analisis bivariat dilakukan untuk mengetahui pengaruh promosi kesehatan reproduksi terhadap pengetahuan remaja. Analisis dilakukan dengan menggunakan Wilcoxon signed rank test.

\section{HASIL}

\section{Analisis Univariat}

Hasil penelitian ini menunjukkan responden paling banyak adalah responden laki-laki berjumlah 36 reaponden (61\%) kemudian perempuan berjumlah 23 responden (39\%).

Berdasarkan usia responden paling banyak adalah responden dengan usia 12 tahun berjumlah 32 responden $(54,2 \%)$. Responden paling muda berusia 11 tahun sebanyak 20 responden $(33,9 \%)$ dan yang paling tua berusia 13 tahun sebanyak 7 responden (11,9\%). 35 responden $(59,3 \%)$ memiliki pengetahuan tentang kesehatan reproduksi yang kurang, sementara 24 responden $(40,7 \%)$ memiliki pengetahuan yang baik.

Penilaian pengetahuan setelah mendapat promosi kesehatan, dari total 59 responden 46 responden (78\%) memiliki pengetahuan tentang kesehatan reproduksi yang cukup, sementara 13 responden (22\%) memiliki pengetahuan yang kurang.

\section{Analisis Bivariat}

Hasil analisis seperti yang ditampilkan pada Tabel 3 menunjukan bahwa dari total 59 responden, 51 responden $\quad(86 ., 4 \%) \quad$ mengalami peningkatan pengetahuan setelah diberikan promosi kesehatan reproduksi, sementara 3 responden $(5,1 \%)$ tidak mengalami perubahan dan $5(8,5 \%)$ responden justru mengalami penurunan pengetahuan. Berdasarkan uji statistik didapatkan nilai $\mathrm{p}=0,001$ yang berarti terdapat pengaruh 
yang signifikan dari pemberian promosi kesehatan reproduksi $(\mathrm{p}<0,05)$ terhadap pengetahuan remaja di SMP Negeri 4 Kecamatan Tomohon Barat Kota Tomohon

\section{PEMBAHASAN}

Berdasarkan distribusi usia, responden pada penelitian ini berusia dari 11-13 tahun dengan jenis kelamin responden dalam penelitian ini paling banyak merupakan laki-laki sebanyak 61 persen, sementara responden wanita hanya berjumlah 39 persen.

Remaja laki-laki maupun perempuan sama-sama dapat terpapar masalah yang berhubungan dengan kesehatan reproduksi. Remaja wanita yang mengalami masalah kesehatan reproduksi sebagian besar terdampak karena terjadinya kehamilan pada usia dini. Masalah yang terjadi pada remaja wanita yang mengalami kehamilan usia dini bisa bersifat psikologis maupun kesehatan. Sebuah penelitian di RSUP Prof. DR. R. D. Kandou mendapatkan bahwa dari 8.499 kehamilan pada tahun 2013 dan 2014 sebanyak $1.066(12,54)$ merupakan kehamilan yang terjadi pada wanita dibawah usia 20 tahun, 1,6 persen diantaranya adalah kehamilan pada usia di bawah 14 tahun. Pada hasil selanjutnya ditemukan berbagai masalah kesehatan yang dialami Ibu baik pada masa kehamilan seperti; anemia, oligohidramnion, ketuban pecah dini, serta preeklampsi-eklampsi. Komplikasi lainnya juga dialami oleh ibu hamil usia dini ketika melahirkan seperti; inersia uteri dan perdarahan post partum. Komplikasikomplikasi-komplikasi tersebut juga mempengaruhi bayi yang dilahirkan.

Paparan informasi merupakan hal yang dapat mempengaruhi perilaku seksual pada remaja. Jika responden mendapatkan informasi kesehatan reproduksi remaja yang baik, maka diperkirakan perilaku seksual yang berbahaya yang dilakukan responden dapat berkurang. Keterpaparan media berupa tayangan pornogradi dan sikap yang mendukung hubungan seksual pranikah merupakan prediktor yang kuat bagi ditampilkannya perilaku hubungan seksual pranikah.

Pengetahuan Sebelum Mendapat Promosi Kesehatan Reproduksi Sebelum menerima promosi kesehatan reproduksi 59,3 persen responden memiliki tingkat pengetahuan yang kurang (jawaban benar kuesioner <65\%). Hasil yang sama ditemukan pada penelitian yang dilakukan oleh Irawan pada tahun 2016 di Desa Kertajaya. Hasilnya menunjukkan 93 persen responden memiliki tingkat pengetahuan $<75 \%$. Beberapa faktor mempengaruhi hasil seperti itu pada 
penelitian lainnya diperkirakan karena kurangnya informasi kesehatan reproduksi yang diterima oleh responden.

Pada penilaian pre-test ditemukan bahwa nilai pengetahuan responden tentang kesehatan reproduksi memiliki nilai yang kurang, hal ini sejalan dengan penelitian Astuti pada 2011 pada siswasiswi SMA menemukan hasil bahwa 76,1 $\%$ dari subyek yang memiliki pengetahuan rendah dan 29,9 \% dari subjek yang memiliki pengetahuan tinggi tentang kesehatan reproduksi yang cenderung melakukan hubungan seksual pra nikah.

Kurangnya pengetahuan remaja tentang kesehatan reproduksi remaja terutama tentang topik kehamilan dan pubertas ditakutkan dapat menyebabkan peningkatan angka kehamilan usia dini. ${ }^{(8)}$

Pengetahuan tentang kesehatan reproduksi yang rendah dapat memberi dampak yang negatif, seperti perilaku seksual yang tidak aman. Berdasarkan penelitian Suidhan, Seweng dan Noor pada tahun 2013 menunjukan bahwa perilaku seks berat pada mahasiswa lebih banyak dilakukan oleh mahasiswa yang memiliki pengetahuan rendah tentang kesehatan reproduksi. ${ }^{(9)}$

Pengetahuan Setelah Mendapat Promosi Kesehatan Reproduksi ,Penelitian
Romulo pada tahun 2014 menyimpulkan bahwa pengetahuan kesehatan reproduksi memiliki pengaruh yang sangat besar terhadap perilaku seksual remaja. Pada penelitian yang dilakukan di SMP Anggrek Banjarmasin ditemukan bahwa semakin tinggi tingkat pengetahuan remaka tentang kesehatan reproduksi maka akan semakin rendah perilaku seksual yang akan dilakukan.

Pengaruh Promosi Kesehatan Reproduksi Terhadap Pengetahuan Remaja, Promosi kesehatan menurut WHO adalah proses mengupayakan individuindividu dan masyarakat untuk meningkatkan kemampuan mereka dalam mengendalikan faktor-faktor yang mempengaruhi kesehatan sehingga dapat meningkatkan kesehatannya.

Setelah dilakukan promosi kesehatan tentang kesehatan reproduksi terjadi peningkatan nilai pengetahuan yang dimiliki oleh responden penelitian. Hal ini sejalan dengan hasil penelitian yang dilakukan oleh Purwono yang mengatakan bahwa metode ceramah efektif untuk meningkatkan pengetahuan remaja tentang stress, juga memberi arti bahwa metode yang dilakukan oleh peneliti dapat membantu keefektifan dalam peningkatan pengetahuan siswa terhadap kesehatan reproduksi remaja. 


\section{KESIMPULAN}

Terdapat perbedaan pengetahuan responden sebelum dan sesudah diberikan promosi Secara statistik terdapat Pengaruh yang signifikan dengan nilai $\mathrm{p}=0,01(\mathrm{p}<$ $0,05)$.

\section{SARAN}

Pemberian promosi kesehatan reproduksi dapat dilakukan dengan berkelanjutan baik oleh pihak sekolah maupun pemerintah yang berwenang pada bidang kesehatan sehingga remaja yang rentang terhadap masalah-masalah kesehatan reproduksi dapat berkurang.

\section{DAFTAR PUSTAKA}

1. Nasution SL. Pengaruh Pengetahuan Tentang Kesehatan Reproduksi Remaja Terhadap Perilaku Seksual Pranikah Remaja Di Indonesia. Widyariset. 2012;15(1).

2. Maryatun. Peran Teman Sebaya terhadap Perilaku Seksual Pra Nikah pada Remaja di SMA Muhammadiyah 3 Surakarta. Gaster. 2013;10(1).

3. Sarapang M. Faktor Yang Mempengaruhi Perilaku Seks Bebas Pada Remaja Di SMU Negeri 7 Manado. 2013.

4. Kasim F. Dampak Perilaku Seks Beresiko Terhadap Kesehatan Reproduksi dan Upaya Pencegahannya. J Stud Pemuda. 2014;3(1).

5. Abdurrajak K, Mamengko LM, Wantania JJE. Karakteristik Kehamilan dan Persalinan <20 Tahun di RSUP Prof. DR. R.D. Kandou Manado Periode Januari 2013-Desember 2014. J eClinic. 2016;4(1).

6. Rahyani KY, Utarini A, Siswanto A, Hakimi M. Perilaku Seks Pranikah Remaja. J Kesehat Masy Nas. 2012;7(4):180-5.

7. Astuti D, Sukasno. Hubungan pengetahuan remaja tentang kesehatan reproduksi dengan perilaku seksual kelas XI di SMAN Gebog Kudus. J Kepererawatan dan kebidanan. 2011;2(1):59-76.

8. Hidayangsi PS. Perilaku Berisiko Dan Permasalahan Kesehatan Reproduksi Pada Remaja. Jakarta: Kemenkes RI; 20145.

9. Suidhan A, Seweng A, Noor N. Hubungan pengetahuan kesehatan reproduksi dengan prilaku seks remaja akhir pada mahasiswa kesehatan dan non kesehatan di Kab. Mamuju Prov. Sulawesi Barat. J Kesehat Reproduksi. 2014;

10. Romulo HM, Akbar SN, Mayangsari DM. Peranan Pengetahuan Kesehatan Reproduksi Terhadap Perilaku Seksual Remaja Awal. 2014.

11. Fitriani S. Promosi Kesehatan. Yogyakarta: Graha Ilmu; 2011.

12. Purwono A. Efektifitas pendidikan kesehatan terhadap peningkatan pengetahuan tentang stress melalui ceramah pada remaja di SMPN 34 Semarang. Semarang: Program Studi Ilmu Keperawatan Fakultas Kedokteran, Universitas Diponegoro; 2009. 